\title{
ОСОБЛИВОСТІ ОРГАНІЗАЦІЇ СЛУЖБИ ШВИДКОЇ МЕДИЧНОЇ ДОПОМОГИ В ПОЛЬЩІ
}

О. В. Олійник

ДВНЗ “Тернопільський держсавний медичний університет імені І. Я. Горбачевського МОЗ Украйни”

\section{PECULIARITIES OF ORGANIZATION OF SERVICE OF URGENT MEDICAL AID IN POLAND}

\author{
O. V. Oliynyk \\ SHEI "Ternopil State Medical University by I. Ya. Horbachevsky of MPH of Ukraine”
}

\begin{abstract}
У статті описується історія, особливості структури та функціонування служби швидкої медичної допомоги в Польщі. Дається характеристика такої спеціальності, як медичний рятівник, яка відсутня в Україні.
\end{abstract}

The history, peculiarities of structure and functions of service of urgent medical aid are described in the article. Specialization of a paramedic, which is absent in Ukraine, is characterized.

Вступ. Україна в даний час знаходиться на етапі реформування служби швидкої та екстреної медичної допомоги. Звісно, що досвід сусідньої Польщі в справі організації цієї служби може мати неабияке значення для розвитку нашої.

У світі існують дві основні моделі служб невідкладної медичної допомоги, відомі за основними принципами роботи - англо-американським “взяти і везти" та німецько-французьким “перебувати і лікувати”.

Перша модель характеризується наявністю такої спеціальності, як медичний рятівник. У США їх називають парамедиками. В Німеччині та Франції ще збереглися лікарські бригади швидкої допомоги, а от у США й англомовних країнах - Англії, Австраліїна виклики пацієнтів виїжджають виключно парамедики, або рятівники. Вони надають допомогу на догоспітальному етапі, а лікарі з невідкладних станів працюють у відповідних відділеннях лікарні і надають пацієнтам вже госпітальну допомогу. 3 країн Східної Свропи шляхом реформування служби швидкої медичної допомоги однією 3 перших пішла Польща: 32007 року в ній було введено професію та спеціалізацію “медичного рятівника”, яка є тотожною спеціальності парамедика в США. У більшості країн світу спеціалізованих бригад швидкої медичної допомоги немає. Відмінністю роботи закордонних бригад невідкладної швидкої допомоги є те, що вони працюють за одним протоколом надання медичної допомоги. В Україні досі було кілька протоколів: для кожної спеціалізованої бригади - окремий протокол.
Основна частина. Невідкладна медична допомога народилася на полі бою. Першу спробу організувати цю галузь медичної служби було зроблено під час Наполеонівських війн під керівництвом Жана Домініка. Він використовував у лікувальній практиці “летючі" кінні вози в битві, щоб допомогти пораненим. У США перші спроби надання медичної допомоги на полі бою з'явилися під час Громадянської війни (1861-1865). Нова планка якості в організації медичної допомоги пораненим на полі бою була зроблена французькою армією в битві при Сольферіно в 1859 році.

У Європі перші спроби організувати екстрену допомогу відбувалися в кінці вісімнадцятого століття. В 1767 році в Амстердамі було створено лікарню, у якій надавали допомогу утопленикам. В 1772 році в Парижі було створено першу станцію швидкої допомоги. Значним поштовхом до розвитку невідкладної допомоги була пожежа у Віденському театрі в 1881 році, в якій загинуло 386 осіб.

Перша станція швидкої допомоги на території Польщі була створена у Кракові в 1891 році з ініціативи доктора медицини Арнольда Беннета. В 1893 році подібна станція була відкрита у Львові. Після цього такі заклади відкрилися у Варшаві (1897), Лодзі (1899), Вільнюсі (1902), Любліні (1917), а потім у Білостоці, Познані, Торуні та Кракові. Вони мали статус юридичних осіб, були незалежними і керувалися своїми статутами. На цих станціях постійно працювало по кілька лікарів. Великі рятувальні станції існували

() О. В. Олійник 
у восьми містах, в 106 містах з'явилися спеціальні рятувальні пункти, 3 яких тільки 24 мали свої власні транспортні засоби.

Новий етап розвитку служби відбувся після закінчення Другої світової війни, коли в кожному населеному пункті із населенням від 5 до 30 тисяч мешканців організовано станції швидкої допомоги із 12 посадами лікарів.

В 1948 році було випущено резолюцію Польського Червоного Хреста, яка регламентувала організацію таких станцій, їх цілодобову роботу, особливості функціонування санітарного транспорту. Діяльність усіх станції мала бути об'єднана. Усі станції повинні були бути відкриті 24 години на добу, в будні ісвята. Бригади швидкої допомоги складались із лікаря, фельдшера і водія або фельдшера і водія. В післявоєнний період було відкрито багато станцій у сільській місцевості.

Одним із найближчих до України воєводств в Польщі є Люблінське воєводство. Ось деяка інформація про історію виникнення служби швидкої допомоги в Любліні. Перші спроби організувати службу швидкої допомоги в Любліні відбулася в 1907 році, коли група лікарів і соціальних працівників звернулися до російської місцевої влади $з$ проханням організувати, як в інших містах, станцію швидкої медичної допомоги. Проте на це було відмовлено. Станція була відкрита при австрійській окупації Любліна 16 січня 1917 року. Муніципалітет купив пару коней, платив гроші на їх утримання та на медикаменти для потерпілих. Проте фінансові проблеми призвели до припинення роботи станції 1 квітня 1920 року. До 1926 року станція працювала з перервами, а з 1926 року постійно. Кошти на функціонування станції платили страхові компанії. Відповідно послугами станції могли скористатись тільки застраховані особи. Спочатку персонал станції працював добровільно і безкоштовно. У травні 1919 року страхова компанія найняла першого штатного співробітника - фельдшера.

У 1923 році за ініціативою редактора газети “Люблін” Теодора Кашинського було оголошено збір коштів на придбання нових транспортних засобів для екстреної служби. Була куплена нова кінна упряж. Перший автомобіль швидкої допомоги вийшов на вулиці Любліна тільки в 1937 році.

Під час Другої світової війни, за часів німецької окупації, швидка допомога не функціонувала. Після війни було розроблено новий статут і правила функціонування служби швидкої допомоги. Відповідно до зазначених правил, швидка допомога підпорядковувалась муніципальній раді і була частиною міського відділу охорони здоров' я.
29 вересня 1948 року рада міністрів Польщі прийняла постанову про організацію екстреної медичної допомоги на всій території країни. Видано розпорядження про ставки та кошти для функціонування служби. В Любліні було закуплено 5 машин швидкої допомоги чехословацького виробництва Skoda 1100. Офіційне відкриття швидкої медичної допомоги в Любліні відбулося 21 липня 1949 року.

1 січня 1951 року Червоний Хрест передав станцію швидкої допомоги в підпорядкування воєводському відділу охорони здоров' я. 1 жовтня 1969 року була створена перша рятувальна реанімаційна команда “'R", оснащена спеціальним реанімобілем. До складу групи увійшли: анестезіолог, висококваліфіковані медсестри, фельдшери та водій.

У серпні 1978 року було організовано відділ швидкої допомоги в Люблінському шпиталі. 30 листопада 1998 року станція швидкої допомоги була перетворена в Регіональний центр швидкої допомоги з трьома підстанціями. Перетворення було пов' язано з набранням чинности нових законів, які регламентували діяльність охорони здоров'я в цілому і швидкої допомоги зокрема.

3 метою подальшого підвищення ефективності роботи служби швидкої допомоги, або рятівництва, в 2001 році було розроблено програму "Підвищення ефективності та ефективності надання надзвичайної допомоги в небезпечних ситуаціях у Люблінському воєводстві", авторами якої були доктора Збігнєв Хуперт та Аліса Цєхан. Програма передбачала значну оптимізацію роботи центру в радіусі 15 км на площі 30 квадратних кілометрів у міському районі, де мешкало 100000 осіб. В 2001 році створено Міський центр оповіщення, який керував роботою служби.

Таким чином, процес реформування польської системи охорони здоров'я було розпочато в 1989 році у зв' язку з фундаментальними змінами в політичному і економічному стані, але на початку 90-х років минулого століття зміни в системі охорони здоров'я просувалася повільно.

Велике значення для процесу реформ охорони здоров'я стало прийняття закону про реформування охорони здоров'я від 30 серпня 1991 року, який і досі відіграє важливе значення для організації медичної допомоги в Польщі. Наслідком закону було розширення прав більшості закладів охорони здоров'я. Цей закон регламентував розвиток ринку для приватних постачальників медичних послуг.

6 лютого 1997 року в Польщі був прийнятий закон про загальне медичне страхування. Його прийняття було революцією для системи охорони здоров'я в Польщі і було вирішальним протягом тривалого часу, 
оскільки встановлювало нормативи щодо фінансування медичних послуг у країні. Вперше були введені нові економічні правила розрахунку між державою, лікарнями та пацієнтами. Закон передбачав загальне медичне страхування на основі моделі Бісмарка. 31 січня 1999 року (тобто після набрання чинності законом) польська система охорони здоров'я відмовилася від попередньої моделі охорони здоров'я (версія Семашка) зі зміною іiі на страхову модель. Фінансування лікарень тепер залежало від послуг, які надавали лікарні за контрактом, замість державного бюджетування медичних установ. Функціонування нової системи медичного страхування було здійснено за рахунок медичного страхування, яке здійснюється за допомогою так званих лікарняних кас (їх кількість у Польщі дорівнює 17). Впровадження медичного страхування в 1999-2002 роках привело до зростання діапазону і різноманітності медичних послуг.

Для покращання функціонування страхової медицини 23 січня 2003 року було видано закон про Національний фонд охорони здоров' я, який замінив закон про загальне медичне страхування. Було введено новий інститут медичного страхування - Національний фонд охорони здоров'я.

Кожний застрахований громадянин Польщі має право на отримання медичної допомоги, на забезпечення рівного з іншими громадянами доступу до медичних послуг, на вільний вибір лікаря. Застрахований має право на стаціонарне лікування в будь-якій лікарні країни, яка підписала угоду з фондом, проведення діагностичних медичних тестів в усіх медичних закладах країни. Згідно з новим законом, функціонування медичного страхування забезпечується страховою установою, а Національний фонд охорони здоров' я збирає кошти, управляє і укладає договори з постачальниками медичних послуг.

У січні 2007 року президент Польщі Лєх Качинський підписав закон про державне медичне рятівництво. Закон передбачав фінансування медичного рятівництва з бюджету держави. В 2012 році витрачено на медичне рятівництво двісті мільйонів злотих.

\section{Лiтература}

1. Adnet F. Systemy ratownictwa medycznego/ F. Adnet, F. Lapostolle// Med. Intens. Rat. - 2008. - № 11 (1).-P. 47-51.

2. Black J. International EMS Systems: United Kingdom / J. Black, G. Davies // Resuscitation. - 2005. - № 64 (1). - P. 2129.

3. Wronska I. Wybrane zagadnienia z pielegniarstwa
Особливості структури служби рятівництва в Польщі такі. Виклики про нещасні випадки та захворювання приймають у Центрі повідомлення рятівників. У цілій Польщі діє аварійний телефонний номер 112, інтегрований з медичними і пожежними службами та поліцією. До складу системи входять бази медичних автомобілів. Останніх є два види: базисні та спеціальні. До складу системи рятівництва також входять спеціальні авіазагони та відділи рятівництва в шпиталях. Крім керівника закладу рятівництва в Польщі, за його функціонування відповідає також воєвода воєводства, в якому знаходиться заклад.

Реформована система рятівництва активно впливає на підвищення безпеки пацієнтів і допомагає обмежити смертність серед жертв катастроф.

Базисними документами, які регламентують навчання рятівників у Польщі, є розпорядження міністра науки та вищої освіти від 12 липня 2007 рокупро стандарти освіти для окремих дисциплін освіти, а також Постанова міністра освіти і науки Польщі від 5 жовтня 2011 року щодо порядку, умов та рівнів освіти. Також стандарти навчання рятівників у Польщі регламентуються Постановою міністра науки та вищої освіти від 2 листопада 2011 року та Національними рамками кваліфікації вищої освіти. Початкова освіта рятівника триває 7 семестрів протягом 3800 годин. По закінченню навчання рятівники проходять практику в станціях рятівництва та відділах рятівництва лікарень.

У сучасній Польщі використовується англо-американська модель швидкої допомоги, проте лікарі на швидкій допомозі залишаються. Частина бригад складається тільки з рятівників, до частини входять також лікарі. Рятівники готуються за спеціальною програмою, вартість якої нижча вартості підготовки лікаря, проте яка охоплює більшу кількість аспектів щодо невідкладних ситуацій, які потребують екстреної медичної допомоги.

Висновок. Польський досвід реформування системи невідкладної медичної допомоги є цінним і може бути використаним у реформуванні цієї служби в Україні.

europejskiego / I. Wronska, E. Krajewska-Kulak / Wydawnictwo Czelej. - Lublin. - 2007. - P. 63-98. 4. Brongel L. Ogolne zasady dzialania sieci Zintegrowanego Ratownictwa Medycznego; w: Zlota godzina. Czas zycia, czas smierci / L. Brongel, M. Kulis // Wydawnictwo Medyczne. Krakow, 2007.-P. 11-106. 